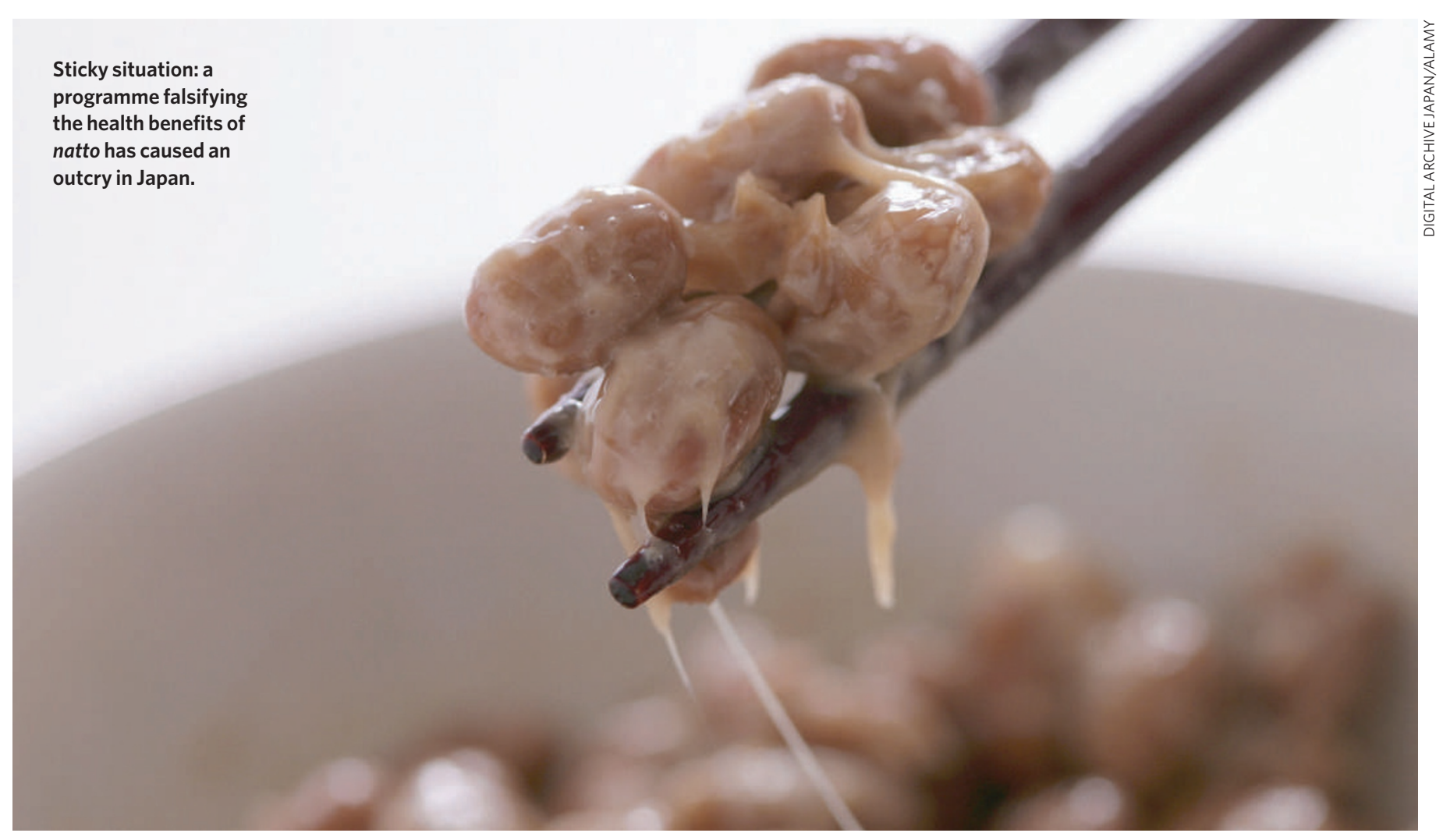

\title{
Japanese TV show admits faking science
}

\section{TOKYO}

For scientists who speak to the mass media about their research, a scandal surrounding a Japanese television show demonstrates just how badly things can go wrong. Kansai Telecasting Corporation (KTV) has admitted that it faked scientific results in one of its programmes, and used dubbing to put false words into the mouths of foreign researchers. After an outcry from the Japanese media, the company has cancelled the series and is reviewing all 520 episodes.

One of the victims is Dr Kim, a professor at a US university who studies soya bean fermentation. He spoke to Nature but asked that his first name and affiliation be withheld. He was interviewed by KTV about his research in January 2006. When he finally watched that programme this month, he was horrified. The show — and Kim - trumpeted the health benefits of a fermented bean paste called miso. "They made it look like I said many things that I didn't. About $60 \%$ of the content was not correct," he says.

Hakkutsu: Aruaru Daijiten II (which roughly translates as "Excavation: an encyclopedia of facts") was a popular weekly show broadcast for ten years by the Fuji Television Network and watched in around 15\% of Japanese homes. Presented as a science documentary, the show covered food and health-related topics and was based on interviews with scientists.

The scandal broke after the broadcast on 7 January, which claimed that eating natto, a pungent dish made from fermented soya beans, can help you lose weight. When the Japanese media raised questions, KTV investigated, and on 20 January released a statement admitting that most of the data in the programme had been fabricated. Photos of slimmed-down people were not of the experimental subjects,
"They made it look like I said many things I didn't." actually those of another researcher.

Schwartz, who is studying the ability of DHEA to slow the progression of age-related diseases, did not respond to Nature's request for an interview, but a university spokeswoman confirmed that "statements were wrongly attributed to Dr Schwartz and his research was falsely represented".

Other incidents have since come to light, including the episode of Aruaru that changed Kim's words. "It looks like I am saying that miso can make you thin and even that it has certain neurological effects," Kim says. He had actuand the claimed measurements of reduced fat levels had never been made.

KTV admitted that it had used Japanese dubbing to put words into the mouth of US researcher Arthur Schwartz of Temple University in Philadelphia. In the 7 January programme, Schwartz appeared to say that isoflavone, a compound in soya beans, can increase the body's levels of dehydroepiandrosterone (DHEA), a naturally occurring hormone said to have various health benefits. Experiments portrayed as having been carried out by Schwartz were ally been explaining why fermenting soya beans makes them more easily digestible and useful as animal feed. "I spent a half-day taking them round my laboratory and showing them results. They understood what I was doing," he says.

Scientific impropriety has been traced back to the early days of the show. In 1998, Aruaru asked Yoichi Nagamura of the Chiba Institute of Science, who researches the soporific effects of tryptophan, to run an experiment investigating whether lettuce makes mice sleepy. Nagamura and the KTV production crew fed 
lettuce extract to some mice and watched them for two hours. "I was hoping to be on TV, and I hoped the mice would fall asleep," he says. But he and the crew agreed that there was no noticeable effect.

So Nagamura was surprised when he saw the programme show one of his mice, declaring: "It's fallen asleep!" Makoto Tajima, a nutrition researcher at Jissen Women's University in Tokyo, then appeared explaining that lactucopicrin, a chemical found in wild lettuce, and in trace amounts in cultivated lettuce, can induce sleep. "The programme left the impression that eating three leaves of lettuce can knock you out," says Nagamura.

Tajima says he's never carried out any experiments with lettuce, but that he gave accurate information from the scientific literature. $\mathrm{He}$ says he felt "a little uncomfortable" explaining another scientist's results, but wasn't too concerned: "We're used like TV personalities, I say what the programme wants me to." Tajima adds that he has appeared on more than 500 television programmes to explain nutrition. "If I didn't do it, they'd get someone worse."

Nagamura says he didn't complain to the production or broadcasting companies, because "it was too ridiculous". But he expressed his misgivings about the show at academic conferences and public talks. "Many scientists would say that Aruaru is dodgy, but nothing happened until now," he says.

Newspaper editorials in Japan are questioning a TV culture in which 'infotainment' is increasingly popular, and contract production companies are chasing ratings, particularly for shows on health and beauty.

Aruaru was cancelled in January because of the scandal, and KTV has asked an independent committee to review all its episodes. It is due to report in mid-March. A 2004 show about the 'science of face-thinning' and a 2001 show about the power of adzuki beans to invigorate the brain are reportedly getting close attention.

Tomohiro Takeuchi, assistant chief of the terrestrial broadcasting division of Japan's internal affairs and communications ministry, says that KTV has technically broken the country's communications law, which prohibits "perversion of the truth", and that his division is waiting for an internal report from KTV, due by the end of February, to decide what action to take. But the ministry's only options are to revoke KTV's broadcasting licence, which Takeuchi says is generally thought too harsh, or censure by "administrative directive/guidance". The stricter penalty has never been applied, and the lesser one in only a few cases. Last year another production company was censured after one of its programmes on how to parch white navy beans for most effective weight loss led to viewers being poisoned.

Earlier this month, the minister of internal affairs and communications called for the next parliament to add other measures, stricter than a directive but less harsh than revoking the licence, to prevent bogus reporting.

Kuniko Takahashi, a nutrition researcher at Gunma University in Maebashi City, says the problem is widespread in Japan. Since 2000 she has been following programmes that combine health and nutrition with entertainment, and has found exaggeration and some dangerous mistakes. "They should all be treated with suspicion," she says. Nevertheless, she worries about the proposed law change. "It would let the government tell us what was right and wrong," she says. "In the end, we'll have to depend on the morals of the people in the industry."

On 26 January, Ichiro Kanazawa, a neurologist and president of the Science Council of Japan, issued a stateof Japan, issued a state-
ment saying that the council's guidelines on academic fraud should apply to anyone doing experiments, even for television shows. He's not optimistic the guidelines will be followed by TV companies, however. "Their goal is not scientific truth; it's ratings," he says. "They are under tremendous pressure."

Cases as blatant as Aruaru are rare, but the temptation to wow an audience at the expense of scientific integrity is not confined to Japan. Last year, Brainiac: Science Abuse, a popular UK science series, admitted that in an episode claiming to show a bathtub of water being blown up by caesium and rubidium, explosives were used instead. Sky One, the channel that broadcast the series, released a statement saying that although it consulted with scientists when planning stunts, its priority in executing them was entertainment. "If you're expecting to see the Open University, you're on the wrong channel!" it said.

Both Kim and Nagamura are now wary of any media. When consenting to be interviewed by Nature, Kim insisted he saw how he was going to be quoted: "That is what I learned from the Aruaru experience."

David Cyranoski 